\title{
PCR DETECTION OF ANAPLASMA PHAGOCYTOPHILUM IN GOAT FLOCKS IN AN AREA ENDEMIC FOR TICK-BORNE FEVER IN SWITZERLAND
}

\author{
SILAGHI C.*, SCHEUERLE M.C.*, FRICHE PASSOS L.M.***, THIEL C.* \& PFISTER K.*
}

\section{Summary:}

Central Switzerland is a highly endemic region for tick-borne fever (TBF) in cattle, however, little is known about $A$. phagocytophilum in goats. In the present study, 72 animals from six goat flocks (373 EDTA blood-samples) in Central Switzerland were analysed for A. phagocytophilum DNA. A real-time PCR targeting the msp2 gene of $A$. phagocytophilum was performed and in positive samples the partial 16S rRNA, groEL and msp4 gene were amplified for sequence analysis. Four DNA extracts were positive. Different sequence types on basis of the amplified genes were found. For comparison, sequences of $A$. phagocytophilum from 12 cattle (originating from Switzerland and Southern Germany) were analysed. The 16S rRNA gene sequences from cattle were all identical amongst each other, but the groEL and msp4 gene differed depending on the origin of the cattle samples and differed from the variants from goats. This study clearly provides molecular evidence for the presence of different types of $A$. phagocytophilum in goat flocks in Switzerland, a fact which deserves more thorough attention in clinical studies.

KEY WORDS: Anaplasma phagocytophilum, tick-borne fever, goat, cattle, PCR, 16S rRNA gene, groEL gene, msp4 gene, Switzerland.

\section{INTRODUCTION}

A naplasma (A.) phagocytophilum is an obligate tick-transmitted intracellular bacterium. It causes granulocytic anaplasmosis in dogs, cats, horses and humans and tick-borne fever (TBF) in ruminants (Rikihisa, 1991). TBF in cattle is characterized by high fever, respiratory symptoms, abortion, a sudden decrease in milk production, leucopenia and can cause severe economic losses in ruminants (Woldehiwet, 2006; Stuen, 2007). However, symptoms may vary depending on the infected species, the variant of A. phagocytophilum involved or the age, condition and immune status of the host (Woldehiwet, 2006; Stuen,

\footnotetext{
* Institute of Comparative Tropical Medicine and Parasitology, Faculty of Veterinary Medicine, Ludwig-Maximilians-University, Leopoldstr. 5, 80802 Munich, Germany.

** Universidade Federal de Minas Gerais, Brazil. Correspondence: Kurt Pfister.

Tel.: 49 (0)89 2180-3622 - Fax: 49 (0)89 2180-3623.

E-mail: kurt.pfister@tropa.vetmed.uni-muenchen.de
}

Résumé : DÉTECTION PAR PCR D'ANAPLASMA PHAGOCYTOPHILUM DANS DES TROUPEAUX DE CHĖVRES D'UNE RÉGION ENDÉMIQUE DE FIĖVRE RÉCURRENTE À TIQUES EN SUISSE

La Suisse centrale est une région hautement endémique de fièvre récurrente à tiques du bétail, mais le rôle d'A. phagocytophilum chez les chèvres n'est pas vraiment connu. Le sang de 72 chèvres provenant de six troupeaux de la Suisse centrale a été analysé (373 échantillons de sang EDTA au total) dans le but de détecter la présence de l'ADN d'A. phagocytophilum. Une réaction PCR en temps réel ciblant le gène msp2 $d^{\prime} A$. phagocytophilum a été réalisée. Dans les échantillons positifs, les gènes partiels 16S rRNA, groEL et msp4 ont été amplifiés afin d'en analyser les séquences. Quatre extraits d'ADN étaient positifs. Différents types de séquences sur la base des gènes amplifiés ont été identifiés. Dans un but de comparaison, des séquences d'A. phagocytophilum trouvés chez 12 bovins originaires d'Allemagne du Sud et de Suisse ont été analysées. Les séquences $d u$ gène $16 \mathrm{~S}$ rRNA étaient toutes identiques quel que soit le bétail, mais les gènes groEL et msp4 étaient variables selon l'origine animale des échantillons, mais également selon l'origine des chèvres. Cette étude apporte l'évidence moléculaire de la présence de différents types $d^{\prime} \mathrm{A}$. phagocytophilum dans les troupeaux de chèvres en Suisse, un résultat qui mérite plus d'attention pour de futures études.

MOTS-CLÉS : Anaplasma phagocytophilum, fièvre récurrente à tiques, chèvre, bovin, $P C R$, gène 16S rRNA, gène groEL, gène msp4, Suisse.

2007). A. phagocytophilum can show great genetic heterogeneity between different geographic regions or host species (reviewed in Woldehiwet, 2006). In sheep flocks, different genetic variants of $A$. phagocytophilum may circulate within one flock (Ladbury et al., 2008). In Switzerland, the first report of TBF in cattle was from the "Bernese Oberland" (Pfister et al., 1987) (Fig. 1) and further evidence of A. phagocytophilum in cattle in Switzerland was given later (HofmannLehmann et al., 2004). Even though there have been isolated reports on outbreaks of TBF in domestic and free-living feral goats, very little is known about the general presence of $A$. phagocytophilum in goats (Foster \& Greig, 1969; Gray et al., 1988). Experimental infections of sheep and goats with $A$. phagocytophilum showed that all animals reacted with fever, rickettsiaemia, lymphocytopenia and reduced packed cell volume (PCV). However, fever in sheep set in earlier and lasted longer than in goats (Gokce \& Woldehiwet, 1999). The main vector for $A$. phagocytophilum in central Europe is Ixodes (I.) ricinus (Linné 1758), which 
is the most abundant tick, also in Switzerland. There, PCR prevalence with A. phagocytophilum in I. ricinus ranges from 0.5 to $2.2 \%$ (Leutenegger et al., 1999; Pusterla et al., 1999b; Liz et al., 2000; Wicki et al., 2000). In the present study, goat flocks in Central Switzerland were investigated with real-time PCR for the presence of A.phagocytophilum. In positive samples, sequence analysis was performed for partial $16 S$ rRNA, groEL and msp 4 gene, comparing A.phagocytophilum appearing in small and large ruminants.

\section{MATERIALS AND METHODS}

$\mathrm{D}$ uring a study on the implementation of the FAMACHA $^{\circ}$ test in goats suffering from gastrointestinal nematodes (GIN), faecal samples and EDTA-blood samples for determination of PCV value, were taken monthly from May to October 2008 from six goat flocks from Central Switzerland (Scheuerle et al., 2010). The EDTA-blood samples were kept frozen at $-26{ }^{\circ} \mathrm{C}$ and were subsequently used in this study for the detection of $A$. phagocytophilum DNA in goats. Due to the frozen state of the samples, it was not possible to use them for serological examination.

The six goat flocks (named A, B, G, J, M, R, according to the first letter of the name of their owners) were situated in the Cantons of Bern, Luzern and Zug (Fig. 1). Their pastures (no stream or wetland; altitude 500-1,100 $\mathrm{m}$ above sea level) were situated on steep hills surrounded by woodland, and hence were potential tick habitats. I. ricinus ticks had been identified previously by exemplary flagging close to the study sites. All animals spent the entire sampling period on the pastures. Each flock consisted of at least one buck, 10 to 100 does with ages ranging from one to 13 years and a lamb group. From each flock, eight to 13 animals were included in the study on GIN and subsequently for this investigation on $A$. phagocytophilum. For flock $\mathrm{R}$ in the month of July, blood samples were not available. Overall 373 samples from 72 individuals were tested.

To compare the sequence variants involved, frozen EDTA-blood samples from $12 \mathrm{~A}$. phagocytophilumpositive cattle were used. The TBF in cattle had been diagnosed positive previously by detection of morulae in the neutrophilic granulocytes in Giemsa-stained blood smears and the blood had been kept frozen. Altogether there were samples from nine cattle (2005), with typical symptoms of clinical TBF (apathy, high fever, sudden decrease in milk production), and three cattle from Southern Germany (2002), with unknown disease status. The Swiss cattle were from the region south of Interlaken, Switzerland and the German cattle from prealpine regions in Germany (Fig. 1). This region in Switzerland is highly endemic for TBF in cattle (P.H. Boss, personal communication).

DNA extraction was carried out with the High Pure PCR template preparation kit (Roche, Mannheim, Germany) according to the manufacturer's instruction. Quality and quantity of extracts was tested with a spectrophotometer (NanoDrop ${ }^{\circledR}$ ND-1000, PeqLab, Erlangen, Germany). A real-time PCR targeting the msp2 gene of $A$. phagocytophilum was performed in an iCycler iQ (Bio-Rad, Munich, Germany) as described previously (Courtney et al., 2004; Silaghi et al., 2008). PCR-grade water served as negative, DNA-extracts of $A$. phagocytophilum-positive ticks as positive controls. For positive samples, further PCRs were carried out: a nested PCR targeting a part (530 $\mathrm{bp}$ ) of the $16 S$ rRNA gene (Massung et al., 1998) was performed in a GeneAmp 9700 thermocycler (Applied Biosystems, Darmstadt, Germany) using primers ge 3 a (5'-CACATGCAAGTCGAACGGATTATTC-3') and ge10r

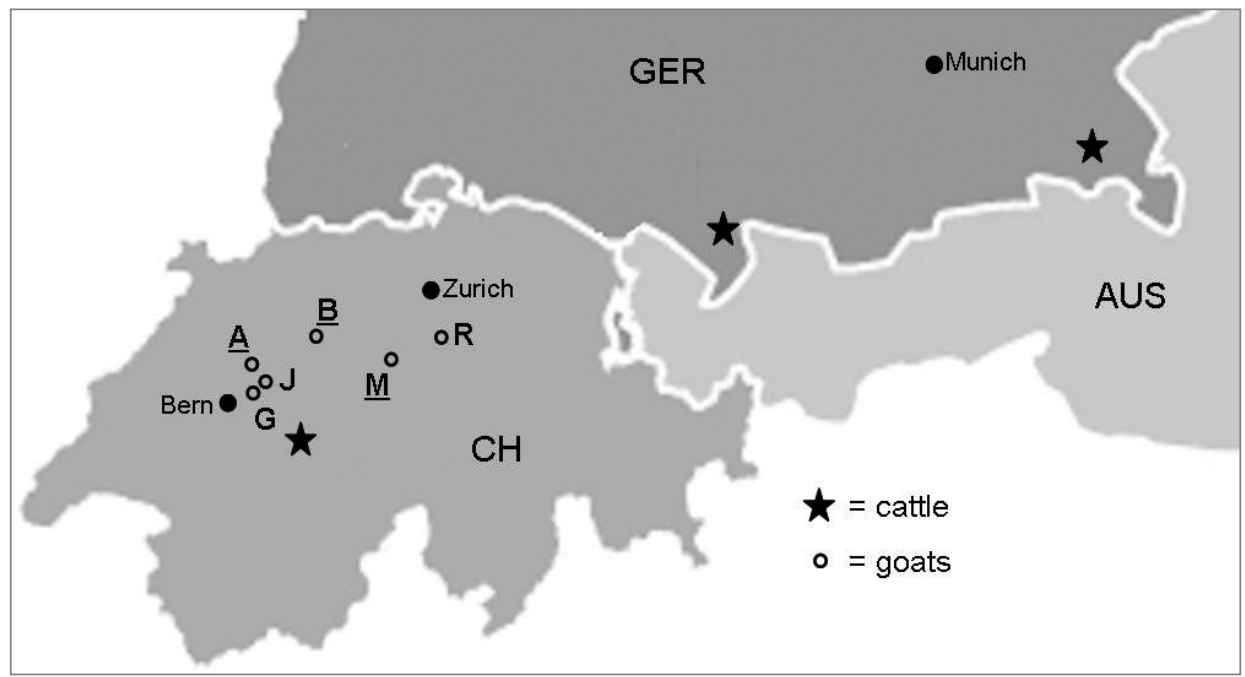

Fig. 1. - Origin of the cattle and goat EDTA-blood samples (May to October 2008), which were investigated for Anaplasma phagocytophilum by real-time PCR.

A, B, G, J, M, R, goat flocks investigated; underlined letter $=$ flocks where $A$. phagocytophilum was found.

AUS, Austria; CH, Switzerland; GER, Germany. 
(5'-TTCCGTTAAGAAGGATCTAATCTCC-3') in the first reaction and primers ge9f (5'-AACGGATTATTCTTTATAGCTTGCT-3') and ge2 (5'-GGCAGTATTAAAAGCAGCTCCAGG-3) in the second amplification. The cycling conditions involved activation of the enzyme at $95{ }^{\circ} \mathrm{C}$ for $15 \mathrm{~min}, 40$ cycles $\left(94^{\circ} \mathrm{C} 30 \mathrm{sec}, 55^{\circ} \mathrm{C}\right.$ $30 \mathrm{sec}, 72{ }^{\circ} \mathrm{C} 1 \mathrm{~min}$ ) and a final extension at $72{ }^{\circ} \mathrm{C}$ for $5 \mathrm{~min}$. Nested amplification used $1 \mu \mathrm{l}$ of primary PCR product for 25 cycles. A groEL gene hemi-nested PCR assay (Alberti et al., 2005) was carried out with initial activation $\left(15 \min 95^{\circ} \mathrm{C}\right), 35$ cycles $\left(95^{\circ} \mathrm{C} 60\right.$ sec, $62{ }^{\circ} \mathrm{C} 60 \mathrm{sec}, 72{ }^{\circ} \mathrm{C} 90 \mathrm{sec}$ ), and final extension $\left(10 \min 72^{\circ} \mathrm{C}\right)$ using primer pair EphplgroEL-F (5'ATGGTATGCAGTTTGATCGC-3') and EphplgroEL-R (5'-TCTACTCTGTCTTTGCGTTC-3') in the first reaction and EphplgroEL-F and EphgroEL-R (5'-TTGAGTACAGCAACACCACCGGAA-3') in the second amplification.

A partial msp4 gene nested PCR was carried out using an approach developed by Bown et al. (2007), using primers MSP4AP5 (5'-ATGAATTACAGAGAATTGCTTGTAGG-3') and MSP4AP3 (5'-TTAATTGAAAGCAAATCTTGCTCCTATG-3') (de la Fuente et al., 2005) followed by a second nested PCR amplification using primers msp4f (5'-CTATTGGYGGNGCYAGAGT-3') and msp4r (5'-GTTCATCGAAAATTCCGTGGTA-3') (Bown et al., 2007). Cycling conditions were $15 \mathrm{~min}$ at $95^{\circ} \mathrm{C}, 40$ cycles $\left(30 \sec 94^{\circ} \mathrm{C}, 45 \sec 54^{\circ} \mathrm{C}, 1 \min 72{ }^{\circ} \mathrm{C}\right.$ ) and final extension $10 \mathrm{~min}$ at $72{ }^{\circ} \mathrm{C}$. Both PCRs were carried out in an Eppendorf Mastercycler gradient (Eppendorf, Hamburg, Germany). The HotStarTaq Polymerase Kit (Qiagen, Hilden, Germany) was used for all PCR experiments in a $50 \mu \mathrm{l}$ reaction volume.

PCR products were visualized under UV light after $2 \%$ Agarose-Gel-Electrophoresis and staining with GelRed $^{\circledR}$ (Biotium, Hayward, USA). After purification with QIAquick PCR Purification Kit according to the manufacturer's instruction (Qiagen, Hilden, Germany), PCR products were sequenced with forward and reverse primers (Eurofins, Martinsried, Germany). The results were evaluated with Chromas $^{\odot}$ Lite (www. technelysium.com.au), sequence homology searches were made by BLASTn analysis of GenBank (www. ncbi.nlm.nih.gov) and multiple alignments performed with ClustalW (www.ebi.ac.uk).

\section{RESULTS}

n general, the same goats were sampled over the entire period, for variations in the number of samples see Table I. Altogether, four of the 373 samples were positive for $A$. phagocytophilum in the real-time PCR. Four different goats were positive and each goat was positive only once. Positive goats were found in three of the six flocks (Fig. 1, Table I). The age of the positive goats ranged from one to five years; one was of unknown age. All positive goats were females. The PCV of the positive goats ranged from 23 to $35 \%$, the physiological range is from 28 to $40 \%$ (Kraft \& Dürr, 1999).

Three different $16 S$ rRNA gene sequence types differing in up to four nucleotide positions from each other were shown (Table II). In flock B, two different sequence types were identified within the same month. One sequence was identical to an $A$. phagocytophilum strain from ticks in Sweden and Germany (GenBank accession nos. AJ242783 and AF136714). The other nucleotide sequence obtained in flock B was also identified in flock M (Table II), identical with another one already obtained from ticks in Sweden and Germany, and also from roe deer in the Czech Republic and humans in Canada (GenBank accession nos. AJ242784, EU839847, AF311343 and AF136713). The sequence type identified in flock A was not $100 \%$ identical with sequences in the GenBank database. Differences between $16 S$ rRNA gene sequences from the present study and selected sequences from the GenBank are shown in Table II. All three differed, for example, in up to three nucleotide positions from the sequence obtained from cattle with TBF from

\begin{tabular}{|c|c|c|c|c|c|c|}
\hline \multirow[b]{2}{*}{ Flock } & \multicolumn{6}{|c|}{$\begin{array}{c}\text { Month } \\
\text { positive goats/total goats tested }\end{array}$} \\
\hline & May & June & July & August & September & October \\
\hline A & $0 / 11$ & $0 / 11$ & $1 / 11$ & $0 / 16$ & $0 / 12$ & $0 / 11$ \\
\hline B & $0 / 11$ & $2 / 11$ & $0 / 7$ & $0 / 11$ & $0 / 12$ & $0 / 12$ \\
\hline G & $0 / 10$ & $0 / 13$ & $0 / 13$ & $0 / 13$ & $0 / 13$ & $0 / 12$ \\
\hline $\mathrm{J}$ & $0 / 7$ & $0 / 8$ & $0 / 8$ & $0 / 8$ & $0 / 8$ & $0 / 7$ \\
\hline M & $0 / 11$ & $0 / 11$ & $0 / 11$ & $0 / 11$ & $0 / 11$ & $1 / 11$ \\
\hline $\mathrm{R}$ & $0 / 10$ & $0 / 10$ & not available & $0 / 11$ & $0 / 10$ & $0 / 9$ \\
\hline Total & $0 / 60$ & $2 / 64$ & $1 / 50$ & $0 / 70$ & $0 / 66$ & $1 / 62$ \\
\hline
\end{tabular}

Table I. - EDTA-blood samples of goats from Central Switzerland, 2008, positive for Anaplasma phagocytophilum in real-time PCR ( $m$ sp2 gene). 


\begin{tabular}{|c|c|c|c|c|c|c|c|c|c|c|c|c|c|c|}
\hline \multirow{2}{*}{$\begin{array}{c}\text { Accession } \\
\text { no. }\end{array}$} & \multicolumn{12}{|c|}{ Nucleotide position $^{a}$} & \multirow[b]{2}{*}{ Host } & \multirow[b]{2}{*}{ Country } \\
\hline & 64 & 76 & 84 & 170 & 175 & 376 & 461 & 463 & 464 & 465 & 467 & 468 & & \\
\hline U02521 & A & A & G & $\mathrm{C}$ & $\mathrm{C}$ & G & $\mathrm{C}$ & $\mathrm{T}$ & G & $\mathrm{C}$ & A & G & Human & USA \\
\hline FJ538288 & $\bullet$ & G & $\mathrm{A}$ & - & - & - & - & - & $\bullet$ & - & - & - & Goat & $\mathrm{CH}^{\mathrm{f}}$ \\
\hline FJ538289c & $\bullet$ & G & $\bullet$ & $\bullet$ & $\bullet$ & $\bullet$ & $\bullet$ & $\bullet$ & $\bullet$ & $\bullet$ & $\bullet$ & $\bullet$ & Goat & $\mathrm{CH}$ \\
\hline FJ538290d & $\bullet$ & $\bullet$ & - & $\mathrm{T}$ & - & A & - & - & - & - & - & - & Goat & $\mathrm{CH}$ \\
\hline FJ538291 & $\bullet$ & $\bullet$ & A & $\bullet$ & $\bullet$ & $\bullet$ & $\bullet$ & - & - & - & - & • & Cattle $^{\mathrm{e}}$ & $\mathrm{CH}, \mathrm{GER}^{\mathrm{g}}$ \\
\hline M73220 & $\bullet$ & $\bullet$ & $\mathrm{A}$ & • & • & $\bullet$ & $\bullet$ & • & - & • & - & • & Sheep & $\mathrm{N}^{\mathrm{h}}$ \\
\hline AF336220 & G & $\bullet$ & A & • & - & • & G & G & A & $\mathrm{T}$ & C & C & Sheep & $\mathrm{N}$ \\
\hline AF084907 & $\bullet$ & $\bullet$ & • & • & - & $\bullet$ & • & - & $\bullet$ & - & - & $\bullet$ & I. ricinus & $\mathrm{CH}$ \\
\hline AF384213 & $\bullet$ & G & A & $\bullet$ & - & $\bullet$ & • & - & - & $\bullet$ & $\bullet$ & $\bullet$ & Roe deer & $\mathrm{CH}$ \\
\hline AF384214 & $\bullet$ & G & A & • & A & $\bullet$ & $\bullet$ & - & - & $\bullet$ & $\bullet$ & • & Roe deer & $\mathrm{CH}$ \\
\hline
\end{tabular}

${ }^{a}$ Nucleotide position in relation to the published prototype sequence of the HGA agent (U02521). Comparison was made for bp 59-584 of the prototype with the obtained 526bp sequence from this study. Dots show identities with the prototype sequence; ${ }^{b}$ nuclotide sequence from goats B10 (June), M8 (October); ${ }^{c}$ nucleotide sequence from B11 (June); ${ }^{\mathrm{d}}$ nucleotide sequence from A8 (July); ${ }^{\mathrm{e}}$ identical sequence obtained from 13 cattle; ${ }^{\mathrm{f}} \mathrm{CH}$, Switzerland; ${ }^{\mathrm{g}}$ GER, Germany; ${ }^{\mathrm{h}} \mathrm{N}$, Norway.

Table II. - Comparison of the 526bp sequences of the $16 \mathrm{~S}$ rRNA gene of Anaplasma phagocytophilum from this study with selected sequences from the GenBank database.

Switzerland, from cattle in Southern Germany and from variants previously shown to be pathogenic for sheep. All cattle were infected with the same $16 S \mathrm{rRNA}$ gene variant, regardless of the geographic origin. The sequences obtained in this study were deposited at GenBank with accession nos. FJ538288 to FJ538291.

The 530 bp partial groEL gene was amplified in the four goats and 12 cattle (GenBank accession nos. GQ452225 to GQ452232). Three caprine variants differed in two nucleotide positions from each other and in 17 nucleotide positions from the fourth variant, which differed in only up to two positions from the variants of bovine origin. Altogether four different groEL variants of bovine origin were detected. All from Switzerland were the same, whereas the three from Germany were different amongst each other and differed from the Swiss one.

Altogether seven different msp4 partial gene variants with differences in a total of 14 nucleotide positions were found. Three different variants were found in the amplified part of the msp4 gene of the goats and four variants were found in the cattle. All Swiss cattle had the same variant, whereas the three German cattle had three different variants. All variants of bovine origin differed from the goat variants (Genbank accession nos. HM028674, HM028675, HM028676, HM028677, HM028678, HM028679, НM028680)

\section{DISCUSSION}

$\mathrm{T}$ The results show the molecular presence of A. phagocytophilum in goats in Central Switzerland. This adds to the knowledge on the epidemiology of A. phagocytophilum in Switzerland, which has been described in the tick I. ricinus (Leutenegger et al., 1999; Pusterla et al., 1999b; Liz et al., 2000; Wicki et al., 2000) and domestic animals like cattle, dogs and horses (Pfister et al., 1987; Pusterla et al., 1997a; Pusterla et al., 1997b; Pusterla et al., 1998a; Hofmann-Lehmann et al., 2004). Serologic evidence has additionally been given in dogs, cattle, red foxes and chamois (Pusterla et al., 1997c; Pusterla et al., 1998b; Pusterla et al., 1999a; Pusterla et al., 1999b; Liz et al., 2002) and also humans (Pusterla et al., 1998c; Weber et al., 2000). Serological or PCR presence of A. phagocytophilum has been described in goats in other countries as well, like Cyprus, Spain and the US (Massung et al., 1998; Amusategui et al., 2006; Chochlakis et al., 2009).

None of the owners of the goat flocks observed any symptoms that could be attributed to $A$. phagocytophilum. However, symptoms of TBF can be very unspecific and the infections may also have been subclinical. The PCR presence of A. phagocytophilum without the development of clinical symptoms has been reported in dogs (Jensen et al., 2007, Galke et al., 2009). Therefore infection in the goats may have been unnoticed so far in the region, despite the endemic presence of $A$. phagocytophilum in ticks (Pusterla et al., 1999b) and in cattle (Pfister et al., 1987). Tickinfestation of the goats was very rarely observed by the owners. However, ticks are easily overlooked by farmers, as a regular examination of goats for ticks does not occur.

In Norway, a flock of lambs showed reduced weight gain in connection with subclinical A.phagocytophilum infection, even though no apparent tick infestation on the pastures was observed (Stuen et al., 2002). Goats in the present study were massively infested with 
gastrointestinal nematodes (GIN) (Scheuerle et al., 2010) and therefore, reduced weight gain or any other clinical signs due to A. phagocytophilum could have been concealed. The PCV of the four goats was mostly in the physiological range. Here also, low PCV values could have been influenced by the detected infection with the GIN Haemonchus contortus (Scheuerle et al., 2010).

In this study, each positive goat was positive only once. Persistence of $A$. phagocytophilum infection in sheep and cattle has previously been shown, resulting in a cyclic parasitaemia, which has been shown in sheep (Stuen et al., 1998; Stuen et al., 2008).

Furthermore, the incubation period in an experimental infection of cattle with $A$. phagocytophilum is between five and nine days and the parasitaemic phase of neutrophils lasts up to two weeks (Pusterla \& Braun, 1997). As samples were taken at monthly intervals, active infection may have been overlooked and the results do not allow conclusion to be drawn for the entire pasture period. The finding of A phagocytophilum DNA in goats is important, as, even though no clinical signs were observed which could typically be connected with TBF, infection with $A$. phagocytophilum is known to increase the susceptibility for secondary infections and could thus contribute to productivity losses. Attention should be paid to keeping goats out of the reach of ticks.

In the investigated goat flocks, three different 165 $r R N A$ gene variants were identified; one flock showed a mixed infection with two different variants in the same month. All these goat variants differed from strains which have previously been shown to be pathogenic for sheep. They also differed from variants from cattle with TBF from the same region in Switzerland.

All $16 S$ rRNA gene sequences in cattle were the same, regardless of the country of origin and the development of clinical symptoms. The clinical cases in the Swiss cattle were very severe, whereas in Germany, no case of TBF in cattle has so far been reported. Therefore, it may well be that host specificity is more important than geographic origin. The groEL gene was amplified in the four goats and 12 cattle. Three caprine variants from three goats were very similar to each other and the fourth one from the fourth goat was very similar to the bovine ones. Four different groEL variants of bovine origin were detected; interestingly, all from Switzerland were the same, whereas the three from Germany differed amongst each other in one nucleotide position. The same was the case for the partial msp4 gene. Therefore, on the basis of these partial genes, there seems to be both geographic and interspecies variation.
The impact of these sequence variations needs further investigation, especially whether there is any influence on the pathogenicity in cattle or the pathogenic potential of $A$. phagocytophilum in goats. Furthermore, future studies need to be undertaken in monitoring active infections, including also the presence of serum antibodies and clinical parameters in goats.

Disclosure: The authors declare that no conflict of interest exists.

\section{REFERENCES}

Alberti A., Zobba R., Chessa B., Addis M.F., Sparagano O., Pinna Parpaglia M.L., Cubeddu T., Pintori G. \& Pittau M. Equine and canine Anaplasma phagocytophilum strains isolated on the island of Sardinia (Italy) are phylogenetically related to pathogenic strains from the United States. Appl Environ Microbiol, 2005, 71, 6418-6422.

Amusategui I., Sainz A. \& Tesouro M.A. Serological evaluation of Anaplasma phagocytophilum infection in livestock in northwestern Spain. Ann N Y Acad Sci, 2006, 1078, 487-490.

Bown K.J., Lambin X., Ogden N.H., Petrovec M., Shaw S.E., Woldehiwet Z. \& Birtles R.J. High-resolution genetic fingerprinting of European strains of Anaplasma phagocytophilum by use of multilocus variable-number tandemrepeat analysis. J Clin Microbiol, 2007, 45, 1771-1776.

Chochlakis D., IoAnnou I., Sharif L., Kokkini S., Hristophi N., Dimitriou T., Tselentis Y. \& Psaroulaki A. Prevalence of Anaplasma sp. in goats and sheep in Cyprus. Vector Borne Zoonotic Dis, 2009, 9, 457-463.

Courtney J.W., Kostelnik L.M., Zeidner N.S. \& Massung R.F. Multiplex real-time PCR for detection of Anaplasma phagocytophilum and Borrelia burgdorferi. J Clin Microbiol, 2004, 42, 3164-3168.

de la Fuente J., Massung R.F., Wong S.J., Chu F.K., Lutz H., Meli M., von Loewenich F.D., GrzeszczuK A., Torina A., Caracappa S., Mangold A.J., Naranjo V., Stuen S. \& Kocan K.M. Sequence analysis of the msp4 gene of Anaplasma phagocytophilum strains. J Clin Microbiol, 2005, 43, 13091317.

Foster W.N.M. \& GREIG J.C. Isolation of tick-borne fever from feral goats in New Galloway. Vet Rec, 1969, 85, 585-586.

Galke D., Pfister K. \& Kohn B. Epidemiologische Studie über Infektionen mit Anaplasma phagocytophilum beim Hund, in: Abstracts of 17. Jahrestagung der FG "Innere Medizin und klinische Labordiagnostik (InnLab)" der DVG, 31 January-1 February 2009, Berlin, Germany. Tieraerztl Praxis 2009, (1), 1-29.

GoKce H.I. \& Woldehiwet Z. Differential haematological effects of tick-borne fever in sheep and goats. Zentralbl Veterinarmed B, 1999, 46, 105-115.

Gray D., Webster K. \& Berry J.E. Evidence of louping ill and tick-borne fever in goats. Vet Rec, 1988, 122, 66.

Hofmann-Lehmann R., Meli M.L., Dreher U.M., Gonczi E., Deplazes P., Braun U., Engels M., Schupbach J., Jorger 
K., Thoma R., Griot C., Stark K.D., Willi B., Schmidt J., KOCAN K.M. \& LuTZ H. Concurrent infections with vectorborne pathogens associated with fatal hemolytic anemia in a cattle herd in Switzerland. J Clin Microbiol, 2004, 42, 3775-3780

Jensen J., Simon D., Murua Escobar H., Soller J.T., Bullerdiek J., Beelitz P., Pfister K. \& Nolte I. Anaplasma phagocytophilum in dogs in Germany. Zoonoses Public Health, 2007, 54, 94-101.

KRAFT W. \& DÜRR U.W. Klinische Labordiagnostik in der Tiermedizin. Schattauer Verlag, Stuttgart, New York, $6^{\text {th }}$ edition, 1999, 57-60.

Ladbury G.A., Stuen S., Thomas R., Bown K.J., Woldehiwet Z., Granquist E.G., Bergstrom K. \& Birtles R.J. Dynamic transmission of numerous Anaplasma phagocytophilum genotypes among lambs in an infected sheep flock in an area of anaplasmosis endemicity. J Clin Microbiol, 2008, 46, 1686-1691.

Leutenegger C.M., Pusterla N., Mishin C.N., Weber R. \& Lutz H. Molecular evidence of coinfection of ticks with Borrelia burgdorferi sensu lato and the human granulocytic ehrlichiosis agent in Switzerland. J Clin Microbiol, 1999, 37, 3390-3391.

Liz J.S., Anderes L., Sumner J.W., Massung R.F., Gern L., RutTi B. \& Brossard M. PCR detection of granulocytic ehrlichiae in Ixodes ricinus ticks and wild small mammals in western Switzerland. J Clin Microbiol, 2000, 38, 1002-1007.

Liz J.S., Sumner J.W., Pfister K. \& Brossard M. PCR detection and serological evidence of granulocytic ehrlichial infection in roe deer (Capreolus capreolus) and chamois (Rupicapra rupicapra). J Clin Microbiol, 2002, 40, 892-897.

Massung R.F., Slater K., Owens J.H., Nicholson W.L., Mather T.N., Solberg V.B. \& Olson J.G. Nested PCR assay for detection of granulocytic ehrlichiae. J Clin Microbiol, 1998, 36, 1090-1095.

Pfister K., Roesti A., Boss P.H. \& Balsiger B. [Ehrlichia phagocytophila as the agent of grazing fever in the Berne highlands]. Schweiz Arch Tierheilkd, 1987, 129, 343-347.

Pusterla N. \& Braun U. Clinical findings in cows after experimental infection with Ehrlichia phagocytophila. Zentralbl Veterinarmed A, 1997, 44, 385-390.

Pusterla N., Deplazes P., Braun U. \& Lutz H. Serological evidence of infection with Ehrlichia spp. in red foxes (Vulpes vulpes) in Switzerland. J Clin Microbiol, 1999a, 37, 1168-1169.

Pusterla N., Huder J., Wolfensberger C., Litschi B., Parvis A. \& LuTz H. Granulocytic ehrlichiosis in two dogs in Switzerland. J Clin Microbiol, 1997a, 35, 2307-2309.

Pusterla N., Huder J.B., Feige K. \& LuTz H. Identification of a granulocytic Ehrlichia strain isolated from a horse in Switzerland and comparison with other rickettsiae of the Ehrlichia phagocytophila genogroup. J Clin Microbiol, 1998a, 36, 2035-2037.

Pusterla N., Leutenegger C.M., Huder J.B., Weber R., Braun U. \& LuTZ H. Evidence of the human granulocytic ehrlichiosis agent in Ixodes ricinus ticks in Switzerland. J Clin Microbiol, 1999b, 37, 1332-1334.

Pusterla N., Pusterla J.B., Deplazes P., Wolfensberger C.,
Muller W., Horauf A., Reusch C. \& LuTz H. Seroprevalence of Ehrlichia canis and of canine granulocytic Ehrlichia infection in dogs in Switzerland. J Clin Microbiol, 1998b, 36, 3460-3462.

Pusterla N., Steiger B., Schorno U. \& Braun U. [Occurrence of bovine ehrlichiosis in the canton Obwalden]. Schweiz Arch Tierheilkd, 1997b, 139, 392-396.

Pusterla N., Weber R., Wolfensberger C., Schar G., Zbinden R., Fierz W., Madigan J.E., Dumler J.S. \& Lutz H. Serological evidence of human granulocytic ehrlichiosis in Switzerland. Eur J Clin Microbiol Infect Dis, 1998c, 17, 207-209.

Pusterla N., Wolfensberger C., Lutz H. \& Braun U. [Serologic studies on the occurrence of bovine ehrlichiosis in the cantons Zurich, Schaffhausen, Thurgau, St. Gallen and Obwalden]. Schweiz Arch Tierbeilkd, 1997c, 139, 543-549.

RikiHISA Y. The tribe Ehrlichieae and ehrlichial diseases. Clin Microbiol Rev, 1991, 4, 286-308.

Scheuerle M., Mahling M., Muntwyler J. \& Pfister K. The accuracy of the FAMACHA(c)-method in detecting anaemia and haemonchosis in goat flocks in Switzerland under field conditions. Vet Parasitol, 2010, 170, 71-77.

Silaghi C., Gilles J., Hohle M., Fingerle V., Just F.T. \& PFISTER K. Anaplasma phagocytophilum infection in Ixodes ricinus, Bavaria, Germany. Emerg Infect Dis, 2008, 14, 972-974.

STUEN S. Anaplasma phagocytophilum - the most widespread tick-borne infection in animals in Europe. Vet Res Commun, 2007, 31 (Suppl 1), 79-84.

Stuen S., Bergstrom K. \& Palmer E. Reduced weight gain due to subclinical Anaplasma phagocytophilum (formerly Ehrlichia phagocytophila) infection. Exp Appl Acarol, 2002, 28, 209-215.

Stuen S., Braten M., Bergstrom K. \& Bardsen K. Cyclic variation in lambs infected with Anaplasma phagocytophilum. Vet Rec, 2008, 163, 338-340.

Stuen S., Engvall E.O. \& Artursson K. Persistence of Ehrlichia phagocytophila infection in lambs in relation to clinical parameters and antibody responses. Vet Rec, 1998, 143, 553-555.

Weber R., Pusterla N., Loy M., Leutenegger C.M., Schar G., Baumann D., Wolfensberger C. \& Lutz H. [Serologic and clinical evidence for endemic occurrences of human granulocytic ehrlichiosis in North-Eastern Switzerland]. Schweiz Med Wochenschr, 2000, 130, 1462-1470.

Wicki R., Sauter P., Mettler C., Natsch A., Enzler T., Pusterla N., Kuhnert P., Egli G., Bernasconi M., Lienhard R., Lutz H. \& Leutenegger C.M. Swiss Army Survey in Switzerland to determine the prevalence of Francisella tularensis, members of the Ehrlichia phagocytophila genogroup, Borrelia burgdorferi sensu lato, and tick-borne encephalitis virus in ticks. Eur J Clin Microbiol Infect Dis, 2000, 19, 427-432.

Woldehiwet Z. Anaplasma phagocytophilum in ruminants in Europe. Ann N Y Acad Sci, 2006, 1078, 446-460.

Received on March $29^{\text {th }}, 2010$ Accepted on September $13^{\text {th }}, 2010$ 